\title{
V(ISn,Al)0_xU) Films Grown by Atomic Layer Deposition
}

\section{Citation}

Heo, Jae Yeong, Yiqun Liu, Prasert Sinsermsuksakul, Zhefeng Li, Leizhi Sun, Wontae Noh, and Roy Gerald Gordon. 2011. \((Sn,Al)0_x ) films grown by atomic layer deposition. Journal of Physical Chemistry C 115(20): 10277-10283.

\section{Published Version}

doi:10.1021/jp202202x

\section{Permanent link}

http://nrs.harvard.edu/urn-3:HUL.InstRepos:8886764

\section{Terms of Use}

This article was downloaded from Harvard University's DASH repository, and is made available under the terms and conditions applicable to Open Access Policy Articles, as set forth at http:// nrs.harvard.edu/urn-3:HUL.InstRepos:dash.current.terms-of-use\#OAP

\section{Share Your Story}

The Harvard community has made this article openly available.

Please share how this access benefits you. Submit a story.

Accessibility 


\section{$(\mathrm{Sn}, \mathrm{Al}) \mathrm{O}_{\mathrm{x}}$ Films Grown by Atomic Layer Deposition}

Jaeyeong Heo, Yiqun Liu, Prasert Sinsermsuksakul, Zhefeng Li, Leizhi Sun, Wontae Noh, and Roy G.

$$
\text { Gordon * }
$$

Department of Chemistry and Chemical Biology, Harvard University, Cambridge, Massachusetts 02138, USA

Tel.: +1-617-495-4017. Fax: +1-617-495-4723

E-mail: gordon@chemistry.harvard.edu 


\section{Abstract}

( $\mathrm{Sn}, \mathrm{Al}) \mathrm{O}_{\mathrm{x}}$ composite films with various aluminum (Al) to tin $(\mathrm{Sn})$ ratios were deposited using an atomic layer deposition technique. The chemisorption behavior of cyclic amide of tin(II) and trimethylaluminum were analyzed by Rutherford backscattering spectroscopy. Both precursors showed retarded and enhanced chemisorption on $\mathrm{Al}_{2} \mathrm{O}_{3}$ and $\mathrm{SnO}_{2}$ surfaces, respectively. The films show highly anisotropic electrical conductivity, i.e. much higher resistivity in the direction through the film than parallel to the surface of the film. The cause of the anisotropy was investigated by cross-sectional transmission electron microscopy, which showed a nanolaminate structure of crystalline $\mathrm{SnO}_{2}$ grains separated by thin, amorphous $\mathrm{Al}_{2} \mathrm{O}_{3}$ monolayers. When the $\mathrm{Al}$ concentration was higher than $\sim 35$ at.\%, the composite films became amorphous, and the vertical and lateral direction resistivity values converged toward one value. By properly choosing the ratio of $\mathrm{SnO}_{2}$ and $\mathrm{Al}_{2} \mathrm{O}_{3}$ subcycles, controlled adjustment of film electrical resistivity over more than 15 orders of magnitude was successfully demonstrated.

\footnotetext{
Jaeyeong Heo, Yiqun Liu, Prasert $(\mathrm{Sn}, \mathrm{Al}) \mathrm{O}_{\mathrm{x}}$ composite films with various Sinsermsuksakul, Zhefeng Li, Leizhi Sun, aluminum to tin ratios were deposited by Wontae Noh, and Roy G. Gordon* using an atomic layer deposition technique. TEM images (right panel) show changes in J. Phys. Chem. C 2011, XX, XXXX microstructure of $(\mathrm{Sn}, \mathrm{Al}) \mathrm{O}_{\mathrm{x}}$ films with increasing $\mathrm{Al}$ concentration from 7.9 to $52.3 \%$ $(\mathrm{Sn}, \mathrm{Al}) \mathrm{O}_{\mathrm{x}}$ Films Grown by Atomic Layer Deposition (scale bar: $5 \mathrm{~nm}$ ). Anisotropic electrical conductivity of composite films was also explained.
} \begin{tabular}{rl}
$7.9 \%$ & $\stackrel{n}{\longrightarrow} 52.3 \%$ \\
& \\
$5 \mathrm{~nm}$ & $5 \mathrm{~nm}$ \\
\hline
\end{tabular} 


\section{Introduction}

Tin oxide $\left(\mathrm{SnO}_{2}\right)$ is a transparent semiconductor with a wide band gap and electrical resistivity as low as $2 \times 10^{-4} \Omega \cdot \mathrm{cm}$ and high infrared reflectivity, over $90 \%{ }^{1-4}$ These properties are achieved using ntype doping by substituting fluorine for about $1 \%$ of the oxygen. ${ }^{5}$ The low electrical resistance and optical transparency in $\mathrm{SnO}_{2}$ are widely used in applications such as solar cells, displays, touch controls and defrosting windows. ${ }^{6,7}$ Its high infrared reflectivity provides its energy saving properties in lowemissivity windows. ${ }^{8}$ Some potential applications of $\mathrm{SnO}_{2}$ would require high instead of low electrical resistance. For example, transparent thin film transistors for displays, ${ }^{9-11}$ microchannel electron multiplier plates, ${ }^{12-14}$ and hole-blocking layers in solar cells ${ }^{15}$ would require highly resistive $\mathrm{SnO}_{2}$ layers that still maintain high electron mobility. Native defects, such as oxygen vacancies and hydroxyl groups, normally contribute electrons to the conduction band. However, high resistivity requires a low concentration of electrons in the conduction band, so electrons from these native defects need to be trapped in order to obtain highly resistive $\mathrm{SnO}_{2}$. Electrons could be trapped by substituting nitrogen for oxygen, or substituting trivalent metals for tin. In this paper, we took the latter approach, and substituted aluminum $\left(\mathrm{Al}^{3+}\right)$ for tin $\left(\mathrm{Sn}^{4+}\right)$. Thus by adding insulating $\mathrm{Al}_{2} \mathrm{O}_{3}$ into $\mathrm{SnO}_{2}$, we explored the possibility of controlling its film resistivity over a wide range, forming $(\mathrm{Sn}, \mathrm{Al}) \mathrm{O}_{\mathrm{x}}$ composite materials. One advantage of using $\mathrm{Al}_{2} \mathrm{O}_{3}$ for modulation of the conducting layer is that it can also be used as the electron emission layer in a microchannel electron multiplier plate. ${ }^{13}$

Atomic layer deposition (ALD) can produce multi-component films with good control of their stoichiometry. This control of stoichiometry even extends to highly conformal films on complex structures with high aspect ratios, such as narrow holes. ALD involves sequential and self-limiting chemical reactions of precursor pulses on the surface of a growing film. ${ }^{16-22}$ As a result, the films can be extremely smooth and continuous without pin-holes. These unique characteristics have made ALD one of the most popular techniques for new application areas of various nanotechnologies. ${ }^{23-25}$ Multi- 
component ALD with the use of more than two cation precursors involves repetitive exposure of different precursors to heterogeneous surfaces. Differing chemisorption amounts of precursors on different oxide surfaces make it difficult to predict the composition of the films. ${ }^{26-29}$ Therefore, in-depth understanding of chemisorption of precursors on heterogeneous surfaces is necessary to control the composition and the electrical, optical, magnetic, and mechanical properties of the resulting films. ${ }^{29-34}$

One process for ALD of $\mathrm{SnO}_{2}$ at low temperature has been reported, but the films were amorphous as deposited, and needed a high-temperature anneal to obtain crystalline material with significant mobility. ${ }^{35}$ A recently reported ALD process overcomes this difficulty by using a more reactive tin source that deposits well-crystallized $\mathrm{SnO}_{2}$ films with reasonably high electron mobility at temperatures as low as $100{ }^{\circ} \mathrm{C} .^{36}$

There have been several efforts to investigate the chemisorption behavior of trimethylaluminum $\left(\mathrm{Al}\left(\mathrm{CH}_{3}\right)_{3}\right.$, TMA) on $\mathrm{ZnO}^{29,32-34,37}$ and $\mathrm{TiO}_{2}{ }^{30}$ surfaces. Elam et al. reported retarded nucleation of both diethylzinc $\left(\mathrm{Zn}\left(\mathrm{CH}_{2} \mathrm{CH}_{3}\right)_{2}\right.$, DEZ) and TMA following the other subcycles by using in-situ quartz crystal microbalance and additional ex-situ measurements of film properties. ${ }^{29,32} \mathrm{Na}$ et al. conducted a similar experiment on Al-doped $\mathrm{ZnO}$ and also confirmed the retarded nucleation of $\mathrm{DEZ}$ on $\mathrm{Al}_{2} \mathrm{O}_{3}$ surfaces. ${ }^{33}$ For $\mathrm{TiO}_{2}$ films, Kim et al. reported retarded adsorption of titanium tetrakis(isopropoxide), $\mathrm{Ti}\left(\mathrm{O}-\mathrm{i}-\mathrm{C}_{3} \mathrm{H}_{7}\right)_{4}$, (TTIP) on $\mathrm{Al}_{2} \mathrm{O}_{3}$ surfaces and observed enhanced chemisorption of TMA on $\mathrm{TiO}_{2}$ surfaces. ${ }^{30}$

Here, we report enhanced chemisorption of TMA on $\mathrm{SnO}_{2}$ surfaces by using Rutherford backscattering spectroscopy (RBS) for analysis of films with various Sn to Al ratios. Hydrogen peroxide $\left(\mathrm{H}_{2} \mathrm{O}_{2}\right)$ was used as the oxygen source. After the first subcycle of TMA- $\mathrm{H}_{2} \mathrm{O}_{2}$ on a $\mathrm{SnO}_{2}$ surface, the chemisorption of next TMA dose was reduced to its usual value on $\mathrm{Al}_{2} \mathrm{O}_{3}$. This result suggests that one subcycle of TMA- $\mathrm{H}_{2} \mathrm{O}_{2}$ almost completes one monolayer formation of $\mathrm{Al}_{2} \mathrm{O}_{3}$ on a $\mathrm{SnO}_{2}$ surface. Electrical anisotropy of the films was revealed by comparison of resistance measurements in the vertical and lateral directions. This anisotropy was correlated with the microstructure of the composite films revealed by transmission electron microscopy (TEM). By properly controlling the number of $\mathrm{SnO}_{2}$ and $\mathrm{Al}_{2} \mathrm{O}_{3}$ cycles, the film's resistivity could be controlled over more than 15 orders of magnitude. The 
present study provides important insight into the chemisorption behaviors of ALD precursors on heterogeneous surfaces and their correlation with the electrical and microstructural properties of composite materials.

\section{Experimental procedure}

$(\mathrm{Sn}, \mathrm{Al}) \mathrm{O}_{\mathrm{x}}$ thin films were formed using a custom-built hot-wall ALD reactor (volume $=0.627$ liters) at growth temperature of $120{ }^{\circ} \mathrm{C}$. A cyclic amide of tin (CAT), 1,3-bis(1,1-dimethylethyl)-4,5dimethyl-(4R,5R)-1,3,2-diazastannolidin-2-ylidene, was used as a precursor for tin. ${ }^{36}$ Figure 1 shows its molecular structure. CAT was sublimed at $40{ }^{\circ} \mathrm{C}$ for purification, at which temperature it has a vapor pressure of 0.42 Torr. The oxygen precursor was vapor from $50 \mathrm{wt}$.\% hydrogen peroxide $\left(\mathrm{H}_{2} \mathrm{O}_{2}\right.$, Sigma Aldrich) kept at room temperature. Three doses of CAT and $\mathrm{H}_{2} \mathrm{O}_{2}$ were required for saturation of the growth rate for $\mathrm{SnO}_{2}$, corresponding to total exposures of 1.9 and $1.5 \mathrm{Torr} \cdot \mathrm{s}$, respectively. The saturated growth rate for $\mathrm{SnO}_{2}$ was $\sim 0.175 \mathrm{~nm} /$ cycle, as reported elsewhere. ${ }^{36}$ The purge time after each dose was set to be $25 \mathrm{~s}$ and $45 \mathrm{~s}$, respectively. TMA (Sigma Aldrich) was used as the Al precursor. It was kept at room temperature, vaporized into a trap volume $(\sim 3 \mathrm{~mL})$ made of stainless steel and subsequently delivered to the reaction chamber by using pneumatic valves. Two doses for both TMA and $\mathrm{H}_{2} \mathrm{O}_{2}$ were enough to obtain saturated growth $(\sim 0.1 \mathrm{~nm} /$ cycle $)$ of $\mathrm{Al}_{2} \mathrm{O}_{3}$ at $120{ }^{\circ} \mathrm{C}$, corresponding to total exposures of 0.24 Torr's for TMA and 0.17 Torr's for $\mathrm{H}_{2} \mathrm{O}_{2}$. Exposure of 0.01-0.1 Torr's for both TMA and $\mathrm{H}_{2} \mathrm{O}$ is known to be sufficient to obtain saturation of the film surface in the TMA- $\mathrm{H}_{2} \mathrm{O}$ ALD process. ${ }^{38}$ This saturated growth per cycle is similar to the value reported by Kumagai et al,, who used the same precursors (TMA/ $\mathrm{H}_{2} \mathrm{O}_{2}$ ). ${ }^{39}$ Purge time for both TMA and $\mathrm{H}_{2} \mathrm{O}_{2}$ precursors was set to $60 \mathrm{~s}$ to completely remove excess precursor vapor and prevent any gas-phase reactions.

The $(\mathrm{Sn}, \mathrm{Al}) \mathrm{O}_{\mathrm{x}}$ composite growth sequence consists of $n$ subcycles of $\mathrm{SnO}_{2}$, followed by $l$ subcycles of $\mathrm{Al}_{2} \mathrm{O}_{3}$, making one complete supercycle. Each subcycle consists of $\mathrm{Sn}$ (or $\mathrm{Al}$ ) dose/ purge/ $\mathrm{H}_{2} \mathrm{O}_{2}$ dose/ purge steps. The $\mathrm{SnO}_{2} / \mathrm{Al}_{2} \mathrm{O}_{3}$ supercycle was repeated by $m$-times. Here, the following 
notation is used for convenience in this study: $m(n, l)$ where $m, n$, and $l$ represent the total number of repetitions of the supercycle, the total number of $\mathrm{SnO}_{2}$ and $\mathrm{Al}_{2} \mathrm{O}_{3}$ subcycles, respectively. Total growth cycles $[m \times(n+l)]$ were set to be 300 cycles except for $\mathrm{AlO}_{\mathrm{x}}$ growth where 400 cycles were used. $60(3,2)$ and 60(2,3) sequences were used for the high $\mathrm{Al}$ atomic concentrations. $m(n, 1)$ sequences were used for targeting $(\mathrm{Sn}, \mathrm{Al}) \mathrm{O}_{\mathrm{x}}$ with less aluminum. Table I summarizes all the sequences that were used in the present study in addition to their measured $\mathrm{Al}$ atomic percentages, calculated ones, film densities, and refractive indices.

The number of chemisorbed $\mathrm{Al}$ atoms per growth cycle and composition of the films were evaluated from ex-situ RBS analysis using $2 \mathrm{MeV} \mathrm{He}^{++}$beam. Glassy carbon (Alfa Aesar) was used as a substrate for RBS analysis, which enables the detection of $\mathrm{O}$ and $\mathrm{Al}$ peaks separated from the substrate background. The simulation error for atomic density was less than $3 \%$, which gives less than \pm 1.5 at. $\%$ variation in calculated Al concentrations. The carbon substrate was cleaned with $10 \%$ aq. HF (5 s), deionized water (30 s), and isopropanol (10 s) prior to drying and ultraviolet-ozone cleaning for 3 min to facilitate the initiation of the film growth. ${ }^{36}$ The areal density of oxygen for an ultraviolet-ozone treated carbon substrate was measured to be $\sim 2 \times 10^{14}$ atoms $/ \mathrm{cm}^{2}$, which does not affect the oxygen signal which comes from a grown oxide film. The film density was calculated using the total mass of Sn, Al, and O atoms from RBS analysis and the film thickness obtained from X-ray reflectivity (XRR, Scintag, XDS 2000). High-resolution TEM (HRTEM, Jeol, JEM-2100) was employed for evaluation of the microstructures of the films.

Lateral-direction film resistivity was evaluated from a four-point probe (Veeco Instruments, FPP100) and circular transmission line measurements. ${ }^{40,41}$ By using the circular transmission line method (inner radius: $50 \mu \mathrm{m}$, outer radii: $54-100 \mu \mathrm{m}$ ), we were able to measure sheet resistance of films up to $\sim 10^{10} \mathrm{ohm} / \mathrm{sq}$. Indium was used for ohmic contacts. ${ }^{42} \mathrm{I}-\mathrm{V}$ measurements were also performed to study the vertical electron flow through the film in order to estimate the thickness-normal resistivity. For the IV measurements, films were deposited on HF-cleaned highly-doped $n$-type Si substrates and $30 \mathrm{~nm} / 2 \mathrm{~nm}$-thick $\mathrm{Au} / \mathrm{Cr}$ top electrodes were formed with a shadow mask in an e-beam evaporator 
(Sharon). The measurement of film thickness and refractive index was performed by spectroscopic ellipsometry (Woollam, WVASE32) and some films were cross-checked by XRR and TEM. Surface morphology of the deposited films was investigated by using atomic force microscopy (AFM, Asylum, MFP-3D SA). Water contact angle measurement (ChemInstruments, CAM-Plus) was performed to study the hydrophilicity of the films.

\section{Results and discussion}

Figure 2 shows RBS spectra of $(\mathrm{Sn}, \mathrm{Al}) \mathrm{O}_{\mathrm{x}}$ composite films grown on glassy carbon substrates. The peaks at the channel numbers of $1270,783,495$, and 328 were assigned to Sn, Al, O, and C, respectively. No other peaks were detected. The inset expands the Al peaks in more detail. The peak Al intensity increases as the number of $\mathrm{Al}_{2} \mathrm{O}_{3}$ subcycles increases. The $\mathrm{Al}$ signal is at the noise level when no $\mathrm{Al}_{2} \mathrm{O}_{3}$ subcycle is used $[300(1,0)]$. The $\mathrm{Sn}$ peak follows the opposite trend to the $\mathrm{Al}$ peak and its intensity increases as the number of $\mathrm{SnO}_{2}$ subcycles increases.

Figures $3 \mathrm{a}$ and $\mathrm{3b}$ show the measured $\mathrm{Sn}$ and $\mathrm{Al}$ content as a function of the relative percentage of $\mathrm{SnO}_{2}$ and $\mathrm{Al}_{2} \mathrm{O}_{3}$ subcycles, respectively. The dotted lines in the figures illustrate the metal content expected from the rule of mixture formula ${ }^{32}$ :

$$
\text { Sn content }(\%)=\left[\rho_{\mathrm{Sn}} \times \% \mathrm{SnO}_{2} /\left(\rho_{\mathrm{Sn}} \times \% \mathrm{SnO}_{2}+\rho_{\mathrm{Al}}\left(100-\% \mathrm{SnO}_{2}\right)\right)\right] \times 100
$$

where $\% \mathrm{SnO}_{2}$ is the percentage of $\mathrm{SnO}_{2}$ subcycles and $\rho_{\mathrm{Sn}}$ and $\rho_{\mathrm{Al}}$ are the area densities of $\mathrm{Sn}$ and $\mathrm{Al}$ atoms per cycle in their pure oxide films, respectively. From the pure $\mathrm{SnO}_{2}$ and $\mathrm{Al}_{2} \mathrm{O}_{3}$ films grown in the present study, $\rho_{\mathrm{Sn}}$ and $\rho_{\mathrm{Al}}$ were found to be 3.67 and 3.35 atoms $/ \mathrm{nm}^{2}$ per cycle, respectively. It is seen from Figure 3a that measured Sn content is below the dotted line predicted from the rule of mixture over the whole range. The $\mathrm{Al}$ content, on the other hand, is always higher than the expected value. The discrepancy becomes most apparent when the percentage of $\mathrm{Al}_{2} \mathrm{O}_{3}\left(\right.$ also $\left.\mathrm{SnO}_{2}\right)$ subcycles is close to $25 \%$ ( $75 \%$ for $\mathrm{SnO}_{2}$ ), which corresponds to $\sim 50$ at. $\%$ of both $\mathrm{Al}$ and $\mathrm{Sn}$. 
The film composition using only $\mathrm{SnO}_{2}$ cycles was measured to be $\mathrm{SnO}_{\mathrm{x}}(\mathrm{x}=2.0-2.1)$ by $\mathrm{RBS}$ analysis. Its film density from RBS and XRR was $5.83 \mathrm{~g} / \mathrm{cm}^{3}$, or $83.4 \%$ of the bulk crystalline value for $\mathrm{SnO}_{2}\left(6.99 \mathrm{~g} / \mathrm{cm}^{3}\right)$. The large volume of grain boundaries appears to be one of the reasons of somewhat low film density compared to the ideal value. ${ }^{36}$ The value is similar to other ALD-SnO $\mathrm{S}_{2}$ film (5.64 $\mathrm{g} / \mathrm{cm}^{3}$ ) reported by Du et al. ${ }^{43}$ After a $350{ }^{\circ} \mathrm{C}$ anneal in nitrogen ambient for $1 \mathrm{hr}$, the film density increased to $\sim 6.0-6.1 \mathrm{~g} / \mathrm{cm}^{3}$. The $\mathrm{Al}_{2} \mathrm{O}_{3}$ film stoichiometry was $\mathrm{AlO}_{\mathrm{x}},(\mathrm{x}=1.5-1.6)$, and its density was $2.83 \mathrm{~g} / \mathrm{cm}^{3}$, or $76.7 \%$ of the bulk crystalline value for $\mathrm{Al}_{2} \mathrm{O}_{3}\left(3.69 \mathrm{~g} / \mathrm{cm}^{3}\right)$. This value of $\mathrm{Al}_{2} \mathrm{O}_{3}$ film corresponds well to the density trend depending on the growth temperature reported by Groner et al. ${ }^{44}$

Figure $3 \mathrm{c}$ shows the calculated film densities by using the total number of atoms counted by RBS and the film thicknesses obtained by XRR. The dotted line represents the expected densities predicted from the rule of mixture:

$$
\text { Film density }\left(\mathrm{g} / \mathrm{cm}^{3}\right)=\left[\rho_{\mathrm{Al} 2 \mathrm{O} 3} \times \% \mathrm{Al}_{2} \mathrm{O}_{3}+\rho_{\mathrm{SnO} 2} \times\left(100-\% \mathrm{Al}_{2} \mathrm{O}_{3}\right)\right] / 100
$$

where $\rho_{\mathrm{Al} 2 \mathrm{O} 3}$ and $\rho_{\mathrm{SnO} 2}$ are film densities of pure $\mathrm{Al}_{2} \mathrm{O}_{3}$ and $\mathrm{SnO}_{2}$ films. It can be seen from Figure $3 \mathrm{c}$ that the actual density values deviate below the expected ones. The refractive indices also followed a similar trend (Table I).

To understand the chemisorption behavior of each metal precursor, the relative atomic concentration of $\mathrm{Sn}$ and $\mathrm{Al}$ per growth subcycle is plotted in Figure 4. Each atomic concentration per subcycle was normalized by its own value, $\mathrm{SnO}_{2}\left(3.67\right.$ atoms $\left./ \mathrm{nm}^{2}\right)$ and $\mathrm{Al}_{2} \mathrm{O}_{3}\left(3.35\right.$ atoms $/ \mathrm{nm}^{2}$ ), respectively. As shown in Figure 4, the relative Sn concentration per cycle (closed squares) gradually decreases as the number of subcycles of $\mathrm{SnO}_{2}$ decreases, which indicates initial retarded chemisorption of $\mathrm{Sn}$ precursor on $\mathrm{Al}_{2} \mathrm{O}_{3}$ surfaces. When the number of $\mathrm{SnO}_{2}$ subcycles is 2 [60(2,3)], the average $\mathrm{Sn}$ concentration per cycle is only $\sim 52 \%$ of pure $\mathrm{SnO}_{2}$. By using the average chemisorption values of CAT on an $\mathrm{Al}_{2} \mathrm{O}_{3}$ surface, we were able to estimate the chemisorption amounts at the initial stages of $\mathrm{SnO}_{2}$ growth on $\mathrm{Al}_{2} \mathrm{O}_{3}$ : the first, second, and third chemisorptions of CAT on $\mathrm{Al}_{2} \mathrm{O}_{3}$ ranged from 30-50, 50-70, and $75-94 \%$, respectively, compared to its chemisorption on $\mathrm{SnO}_{2} .4-5$ incubation cycles were necessary 
before the CAT precursor increased its adsorption per cycle back to its usual amount on $\mathrm{SnO}_{2}$ surface. Similar retarded chemisorption were reported for $\mathrm{DEZ}^{32,33}$ and $\mathrm{TTIP}^{30}$ following $\mathrm{Al}_{2} \mathrm{O}_{3}$ subcycles.

On the other hand, the chemisorption of TMA on $\mathrm{SnO}_{2}$ surface (closed circles) is strongly enhanced, as shown in Figure 4. When one $\mathrm{Al}_{2} \mathrm{O}_{3}$ subcycle is used [i.e. $l=1,12(24,1), 30(9,1)$, and $75(3,1)$ ], about 2.16-times higher chemisorption $\left(7.25\right.$ atoms $\left./ \mathrm{nm}^{2}\right)$ of TMA per cycle was observed compared to its usual number of 3.35 atoms $/ \mathrm{nm}^{2}$ on $\mathrm{Al}_{2} \mathrm{O}_{3}$, which corresponds to $\sim 76 \%$ of one monolayer of $\mathrm{Al}_{2} \mathrm{O}_{3}$ by one growth cycle. ${ }^{22} \mathrm{Kim}$ et al. reported about 1.6-times enhanced chemisorption of TMA on $\mathrm{TiO}_{2}$ surfaces, which was measured by inductively coupled plasma atomic emission spectroscopy. ${ }^{30}$ On $\mathrm{ZnO}$ surface, however, Elam et al. ${ }^{32}$ and $\mathrm{Na}$ et al. ${ }^{33}$ reported contrary chemisorption behavior of TMA although they both used the same $\mathrm{Zn}$ and Al precursors and in-situ quartz crystal microbalance for elemental quantification; Elam et al. ${ }^{32}$ reported retarded chemisorption of TMA for 2-3 cycles on $\mathrm{ZnO}$ surface, whereas $\mathrm{Na}$ et al. ${ }^{33}$ observed the same mass uptake of TMA on $\mathrm{ZnO}$.

The enhanced chemisorption of TMA on $\mathrm{SnO}_{2}$ surfaces remains relatively constant up to the point where the $\mathrm{Al}$ concentration of the composite film is $\sim 50$ at.\% and then it starts to decrease as the $\mathrm{Al}$ concentration increases further. This corresponds to the experiments where either two or three subcycles of $\mathrm{Al}_{2} \mathrm{O}_{3}$ were used $[60(3,2)$ and $60(2,3)]$ instead of one subcycle. For the second TMA- $\mathrm{H}_{2} \mathrm{O}_{2}$ subcycle on $\mathrm{SnO}_{2}$, it appears that the $\mathrm{Al}_{2} \mathrm{O}_{3}$ growth recovers its original value of $\sim 3.35$ atoms $/ \mathrm{nm}^{2}$ per cycle. The sequences of $60(3,2)$ and $60(2,3)$, where the measured $\mathrm{Al}$ concentrations are 58.6 and 76.5 at.\%, respectively, can be used to show this result. If the first and second/third $\mathrm{Al}_{2} \mathrm{O}_{3}$ subcycles on $\mathrm{SnO}_{2}$ have chemisorptions of $\sim 2.16$ and 1 , respectively, relative to their normal values on $\mathrm{Al}_{2} \mathrm{O}_{3}$, then the average chemisorption for two and three $\mathrm{Al}_{2} \mathrm{O}_{3}$ subcycles on $\mathrm{SnO}_{2}$ should be 1.58 and 1.39, respectively. The measured values for these cases were $1.54 \pm 0.08$ and $1.23 \pm 0.08$, which matched reasonably well with the calculated values. This comparison suggests that after the first $\mathrm{Al}_{2} \mathrm{O}_{3}$ subcycle, which forms nearly one monolayer of $\mathrm{Al}_{2} \mathrm{O}_{3}$, subsequent chemisorption of TMA immediately returns to its original behavior like on pure $\mathrm{Al}_{2} \mathrm{O}_{3}$ surface. Thus the underlying $\mathrm{SnO}_{2}$ surface is fairly completely covered by the first $\mathrm{Al}_{2} \mathrm{O}_{3}$ subcycle, so that the $\mathrm{SnO}_{2}$ layer beneath does not influence the second $\mathrm{Al}_{2} \mathrm{O}_{3}$ subcycle. 
Based on these observed chemisorption behaviors of CAT and TMA, an empirical model was derived to calculate the $\mathrm{Al}$ atomic concentration for each sequence. For chemisorption of $\mathrm{CAT}$ on $\mathrm{Al}_{2} \mathrm{O}_{3}$, the first $\mathrm{SnO}_{2}$ subcycle deposited $40 \%$ of its usual amount on $\mathrm{SnO}_{2}$ surfaces. The second deposited $60 \%$, the third $80 \%$, the fourth $90 \%$, and subsequent $\mathrm{SnO}_{2}$ subcycles gave $100 \%$ of the usual growth on $\mathrm{SnO}_{2}$. For chemisorption of TMA on $\mathrm{SnO}_{2}$, the first subcycle deposited $216 \%$ of the amount normally deposited on $\mathrm{Al}_{2} \mathrm{O}_{3}$, and subsequent $\mathrm{Al}_{2} \mathrm{O}_{3}$ subcycles deposited $100 \%$ of the usual amount on $\mathrm{Al}_{2} \mathrm{O}_{3}$. The compositions calculated in this way are fairly well matched with the measured values (Table I).

One of the possible factors that affect the amount of TMA chemisorption is how rough the underlying surface is prior to a $\mathrm{TMA}-\mathrm{H}_{2} \mathrm{O}_{2}$ subcycle. Large surface roughness, i.e. large surface area, could lead to higher chemisorption of TMA per one cycle on $\mathrm{SnO}_{2}$ surface. To study whether the surface area plays an important role for the enhanced chemisorption, surface roughness of the films were measured by AFM after the deposition. Figures 5a-d show the surface morphologies of $\mathrm{SnO}_{2}$ [556(1,0)], 7.9 at.\% Al- $\mathrm{SnO}_{\mathrm{x}}[30(24,1)], 20.4$ at.\% $\mathrm{Al}-\mathrm{SnO}_{\mathrm{x}}[60(9,1)]$, and $\mathrm{Al}_{2} \mathrm{O}_{3}$ films $[910(0,1)]$, respectively. To eliminate the thickness effect and enhance the distinction among samples, the final film thickness of all samples was set to be $\sim 100 \mathrm{~nm}$. Figure 5 e summarizes its root-mean-square roughness $\left(\mathrm{R}_{\mathrm{s}}\right)$ of those samples. The $\mathrm{R}_{\mathrm{s}}$ of the $\mathrm{SnO}_{2}$ film was $3.2 \mathrm{~nm}$. Interestingly, a drastic drop in $\mathrm{R}_{\mathrm{s}}$ of the ( $\mathrm{Sn}, \mathrm{Al}) \mathrm{O}_{\mathrm{x}}$ films to $0.45-0.50 \mathrm{~nm}$ was observed. The roughness of undoped $\mathrm{Al}_{2} \mathrm{O}_{3}$ was similar $(0.55 \mathrm{~nm})$. This result indicates that repetitive $\mathrm{Al}_{2} \mathrm{O}_{3}$ incorporation effectively suppresses the further growth of $\mathrm{SnO}_{2}$ grains, resulting in smaller grain size than that of $\mathrm{SnO}_{2}$. Based on these roughness values, it can be inferred that, when TMA injection occurs, the surface area of $\mathrm{SnO}_{2}$ should not be much larger than that of the pure $\mathrm{SnO}_{2}$. Thus a larger surface area cannot explain the higher adsorption of TMA on $\mathrm{SnO}_{2}$.

It is known that a higher density of hydroxyl groups leads to increased chemisorption of TMA on $\mathrm{Al}_{2} \mathrm{O}_{3} .{ }^{22}$ To compare the density of hydroxyl groups on $\mathrm{ALD} \mathrm{SnO}_{2}$ and $\mathrm{Al}_{2} \mathrm{O}_{3}$ films, static water contact angle measurements were performed. A lower contact angle corresponds to a higher density of hydroxyl groups. The contact angles of $\mathrm{SnO}_{2}$ and $\mathrm{Al}_{2} \mathrm{O}_{3}$ were $33 \pm 1$ and $47 \pm 2$ degrees, respectively. Thus the $\mathrm{SnO}_{2}$ surface appears to contain a higher density of hydroxyl groups than $\mathrm{Al}_{2} \mathrm{O}_{3}$ does, which correlates 
with its higher adsorption of TMA. However, this relatively small difference in the contact angles of $\mathrm{SnO}_{2}$ and $\mathrm{Al}_{2} \mathrm{O}_{3}$ does not fully account for the highly enhanced chemisorption of TMA on a $\mathrm{SnO}_{2}$ surface. ${ }^{45}$ One of the possible contributing factors is the diffusion of $\mathrm{Al}$ ions during the TMA exposure like the $\mathrm{TiO}_{2}$ case where the retarded chemisorption of the Ti precursor was also reported by Kim et al. ${ }^{30,31}$ More detailed study is needed to clarify the origin of the enhanced chemisorption of TMA on a $\mathrm{SnO}_{2}$ surface.

Cross-sectional TEM was used to study how $\mathrm{Al}_{2} \mathrm{O}_{3}$ subcycle affects the microstructure of the growing films. Figures $6 \mathrm{a}$ and $6 \mathrm{~b}$ show the cross-sectional TEM images ${ }^{36}$ of $\mathrm{SnO}_{2}$ grown for the same total growth cycles for comparison (scale bar: $5 \mathrm{~nm}$ ). From the higher magnification image shown in Figure 6b, it is seen that $\mathrm{SnO}_{2}$ grows as a polycrystalline phase (rutile structure) and its grain size varies roughly from 5 to $10 \mathrm{~nm} \cdot{ }^{36}$ It is seen that crystalline grains overlap with each other, which indicates that nucleation and growth of $\mathrm{SnO}_{2}$ grains occurs somewhat in random directions as the film grows. Figures $6 \mathrm{c}$ and $6 \mathrm{~d}$ show the cross-sectional TEM images of 7.9 at.\% $\mathrm{Al}-\mathrm{SnO}_{\mathrm{x}}$ film $[12(24,1)]$ with the same magnification. The film thickness was about $50 \mathrm{~nm}$ and its nominal growth rate was calculated to be $0.166 \mathrm{~nm} /$ cycle, a little smaller than that of $\mathrm{SnO}_{2}$, which is $0.175 \mathrm{~nm} /$ cycle. The observed average grain size of 7.9 at. $\% \mathrm{Al}-\mathrm{SnO}_{\mathrm{x}}$ is $\sim 4-5 \mathrm{~nm}$, which is smaller than that of pure $\mathrm{SnO}_{2}$ (Figure $\left.6 \mathrm{~b}\right)$. The average grain size observed in these images is similar to the thickness roughly expected from the number of $\mathrm{SnO}_{2}$ subcycles (24 cycles) and its growth rate $(0.175 \mathrm{~nm} /$ cycle). Notably, the distribution of grain sizes is narrower than that of $\mathrm{SnO}_{2}$. This indicates that one additional $\mathrm{Al}_{2} \mathrm{O}_{3}$ subcycle for every 24 subcycles of $\mathrm{SnO}_{2}$ inhibits the further growth of pre-existing $\mathrm{SnO}_{2}$ grains. This result suggests that even one subcycle of TMA- $\mathrm{H}_{2} \mathrm{O}_{2}$ effectively screens underlying $\mathrm{SnO}_{2}$ crystallites, which is reasonable based on the enhanced chemisorption of TMA on $\mathrm{SnO}_{2}$ surface. The low roughness of these films can also be explained by this observation. Similarly, Elam et al. observed a renucleation of the ZnO crystal growth on a $\mathrm{Al}_{2} \mathrm{O}_{3}$ layer in a $\mathrm{ZnO} / \mathrm{Al}_{2} \mathrm{O}_{3}$ nanolaminate system. ${ }^{46}$

From Figure 6d, it is also noted that $\mathrm{SnO}_{2}$ crystallites form side-by-side on a plane normal to the growth direction. The thin amorphous layers observed between the $\mathrm{SnO}_{2}$ layers are expected to be $\mathrm{Al}_{2} \mathrm{O}_{3}$ 
or Al-O-Sn. ${ }^{33}$ The number of those amorphous layers is 11 , which is consistent with the total number of subcycles of TMA- $\mathrm{H}_{2} \mathrm{O}_{2}$ except for the last subcycle, which is not distinguishable from the top glue layer. This parallel nucleation and growth of $\mathrm{SnO}_{2}$ crystallites observed from the TEM images indicates that even one subcycle of TMA- $\mathrm{H}_{2} \mathrm{O}_{2}$ blocks the crystalline information of $\mathrm{SnO}_{2}$ underneath and that $\mathrm{Al}$ atoms are not homogeneously mixed with $\mathrm{SnO}_{2}$. A similar periodic peak-and-valley distribution of $\mathrm{Al}$ along the growth direction was also reported in ALD Al-doped ZnO by using secondary ion mass spectroscopy $^{33}$ and cross-sectional TEM $^{37}$.

The 20.4 at. $\%$ Al- $\mathrm{SnO}_{\mathrm{x}}$ film $[30(9,1)]$ was still polycrystalline like the 7.9 at. $\% \mathrm{Al}-\mathrm{SnO}_{\mathrm{x}}$ film (image not shown). However, distinct amorphous layers were not clearly distinguishable for this sample, which appears to be reasonable considering the expected thickness $(<\sim 1.5 \mathrm{~nm})$ of the $\mathrm{SnO}_{2}$ layers between the $\mathrm{Al}_{2} \mathrm{O}_{3}$ layers. Figures $6 \mathrm{e}$ and $6 \mathrm{f}$ show the cross-sectional TEM images of 52.3 at.\% $(\mathrm{Al}, \mathrm{Sn}) \mathrm{O}_{\mathrm{x}}$ film $[75(3,1)]$. Unlike $\mathrm{SnO}_{2}$ and 7.9 at.\% Al-doped $\mathrm{SnO}_{\mathrm{x}}$ cases, the microstructure of the film turned out to be amorphous. Based on the TEM results, the microstructural transition of $(\mathrm{Sn}, \mathrm{Al}) \mathrm{O}_{\mathrm{x}}$ composite films occurs between 20.4 and 52.3 at. $\%$ of Al. The thickness of 20.4 and 52.3 at.\% $\mathrm{Al}-\mathrm{SnO}_{\mathrm{x}}$ films were $\sim 38-40 \mathrm{~nm}$, which corresponds to the nominal growth rate of $\sim 0.13 \mathrm{~nm} / \mathrm{cycle}$. As the percentage of $\mathrm{Al}_{2} \mathrm{O}_{3}$ subcycle increases, the nominal growth rate decreases and approaches to the growth rate of $\mathrm{Al}_{2} \mathrm{O}_{3}(0.10 \mathrm{~nm} /$ cycle $)$.

The inhomogeneous distribution of $\mathrm{Al}$ in $\mathrm{SnO}_{2}$ was further investigated by electrical measurements. I-V measurements were carried out to evaluate the resistance to electron flow through the film perpendicular to its surface. Four point probe measurement was used to find the resistivity in the lateral direction, but the measurement limit was low $\left(<10^{6} \mathrm{ohm} / \mathrm{sq}.\right)$. Thus, only samples with Al concentrations less than $10 \%$ could be measured in this way. Therefore, the circular transmission line method, ${ }^{40,41}$ which provides a higher measurement limit $\left(\sim 10^{10} \mathrm{ohm} / \mathrm{sq}.\right)$, was also used to study lateral electron flow parallel to the surface of the film.

Figure 7a summarizes the observed resistivity of films with various Al concentrations. Here, closed circles and open squares represent resistivity measured perpendicular through the film and laterally 
(parallel) to the film surface, respectively. Even a small amount of $\mathrm{Al}$ incorporated into the $\mathrm{SnO}_{2}$ films $[12(24,1)]$, causes a drastic increase of resistivity measured through the film. This result suggests that even one subcycle of $\mathrm{Al}_{2} \mathrm{O}_{3}$ can dramatically interrupt the vertical electron flow in $\mathrm{SnO}_{2}$ (Figure 7b). On the other hand, the same amount of Al content causes only a small increase in resistivity measured laterally along the plane of the film by the circular transmission line method. The lateral resistivity measured by the circular transmission line method is plotted only up to $\sim 10^{6} \Omega \cdot \mathrm{cm}$ due to limitations of the measurement. As the $\mathrm{Al}$ concentration increases further, the resistivity in perpendicular direction eventually approaches to that of pure $\mathrm{Al}_{2} \mathrm{O}_{3}\left(\sim 4 \times 10^{13} \Omega \cdot \mathrm{cm}\right)$. The resistivity in the lateral direction shows a much slower increase compared to the resistivity in the perpendicular direction. The slow increase in lateral resistivity appears to come from the increased scattering of electrons due to smaller grain sizes observed in TEM images (Figures 6c and 6d) as well as the decreased portion of conducting $\mathrm{SnO}_{2}$.

The 2 to 6 order of magnitude difference in resistivities parallel and perpendicular to the film may be attributed to the inhomogeneous distribution of resistive $\mathrm{Al}_{2} \mathrm{O}_{3}$ between the conductive $\mathrm{SnO}_{2}$ layers. In case of lateral electron flow, current can flow through conductive $\mathrm{SnO}_{2}$ layers instead of resistive $\mathrm{Al}_{2} \mathrm{O}_{3}$ (or Al-Sn-O) layers. For current flowing perpendicular to the film, however, electrons inevitably flow multiple times through the highly resistive $\mathrm{Al}_{2} \mathrm{O}_{3}$ (or Al-Sn-O) layers, leading to a drastic increase in resistivity through the film (Figure 7b). Such anisotropic electrical properties have not been reported for sputter-processed films where a homogeneous mixture of $\mathrm{Al}$ and $\mathrm{Sn}$ is expected. ${ }^{11}$

As the $\mathrm{Al}$ concentration increases over $\sim 20$ at.\%, the lateral resistivity quickly approaches toward the vertical resistivity, as shown in Figure 7a. The actual convergence of those two values could not be observed because of the detection limit of the circular transmission line method. Based on the trend of those two plots, however, they are expected to show close values for films with Al concentration higher than $\sim 35$ at.\% due to the more homogeneous nature of the films (Figure $7 \mathrm{c}$ ). This result is consistent with the TEM observation, where the phase change from crystalline to amorphous state occurred between 20 and 50 at.\% $\mathrm{Al}-\mathrm{SnO}_{\mathrm{x}}$. 


\section{Conclusions}

We studied macroscopic properties of $(\mathrm{Sn}, \mathrm{Al}) \mathrm{O}_{\mathrm{x}}$ composite films, such as density, crystallinity, refractive index, resistivity, roughness, as well as growth rate of each layer, depending on the number of subcycles of $\mathrm{Al}_{2} \mathrm{O}_{3}$ and $\mathrm{SnO}_{2}$. By using RBS analyses, the chemisorption behaviors of the aluminum precursor TMA and the Sn precursor CAT were determined. The chemisorption of TMA on $\mathrm{SnO}_{2}$ surface showed a large enhancement compared to the case of pure $\mathrm{Al}_{2} \mathrm{O}_{3}$. After the first $\mathrm{Al}_{2} \mathrm{O}_{3}$ subcycle, however, the chemisorption of TMA decreased to its original rate after the formation of almost a complete monolayer of $\mathrm{Al}_{2} \mathrm{O}_{3}$. In contrast, the chemisorption of the $\mathrm{Sn}$ precursor on $\mathrm{Al}_{2} \mathrm{O}_{3}$ was greatly retarded and took several cycles to increase back to its usual value on $\mathrm{SnO}_{2}$. These differences were related to the observation that $\mathrm{SnO}_{2}$ surface is more hydrophilic than the $\mathrm{Al}_{2} \mathrm{O}_{3}$ surface. Highly anisotropic electrical properties of the nanolaminate $(\mathrm{Sn}, \mathrm{Al}) \mathrm{O}_{\mathrm{x}}$ films were revealed by comparing I-V and circular transmission line measurements of nanolaminate films. As more aluminum was added, the microstructure changed from nanocrystalline nanolaminate to amorphous, and the anisotropy in the resistivity tended toward zero. By changing the number of $\mathrm{SnO}_{2}$ and $\mathrm{Al}_{2} \mathrm{O}_{3}$ subcycles, the resistivity could be adjusted over 15 orders of magnitude. Detailed study of the chemisorption properties of different precursors can provide insight into the formation and composition of multi-component materials grown by ALD.

\section{Acknowledgements}

The authors thank Dr. Adam S. Hock for synthesizing the Sn precursor. We appreciate discussions with Dr. Philippe de Rouffignac. This work was performed in part at the Center for Nanoscale Systems (CNS) at Harvard University, a member of the National Nanotechnology 
Infrastructure Network (NNIN), which is supported by the National Science Foundation under NSF award no. ECS-0335765. 
Table I. Physical properties of $(\mathrm{Sn}, \mathrm{Al}) \mathrm{O}_{\mathrm{x}}$ composite films for different growth sequences.

\begin{tabular}{cccccc}
\hline$m(n, l)$ & $\begin{array}{c}\text { Al (at.\%) } \\
\text { from rule } \\
\text { of mixture }\end{array}$ & $\begin{array}{c}\text { Al (at.\%) } \\
\text { from RBS }\end{array}$ & $\begin{array}{c}\text { Al (at.\%) } \\
\text { from } \\
\text { model }\end{array}$ & $\begin{array}{c}\text { density } \\
\left(\mathrm{g} / \mathrm{cm}^{3}\right)\end{array}$ & $\begin{array}{c}\text { refractive } \\
\text { index }\end{array}$ \\
\hline $300(1,0)$ & 0 & 0 & 0 & 5.83 & 1.98 \\
$12(24,1)$ & 3.7 & 7.9 & 8.0 & 5.21 & 1.97 \\
$30(9,1)$ & 9.2 & 20.4 & 20.4 & 5.03 & 1.90 \\
$33(8,1)$ & 10.2 & 24.5 & 22.7 & 4.85 & 1.82 \\
$38(7,1)$ & 11.5 & 27.1 & 25.7 & 4.82 & 1.79 \\
$75(3,1)$ & 23.3 & 52.3 & 52.3 & 3.67 & 1.73 \\
$60(3,2)$ & 37.8 & 58.6 & 61.6 & 3.63 & 1.73 \\
$60(2,3)$ & 57.8 & 76.5 & 79.1 & 3.13 & 1.69 \\
$400(0,1)$ & 100.0 & 100.0 & 100 & 2.83 & 1.63 \\
\hline
\end{tabular}


Figure 1.

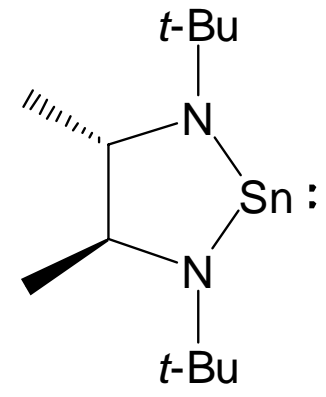

Figure 1. Molecular structure of CAT precursor (1,3-bis(1,1-dimethylethyl)-4,5-dimethyl-(4R,5R)1,3,2-diazastannolidin-2-ylidene). 
Figure 2.

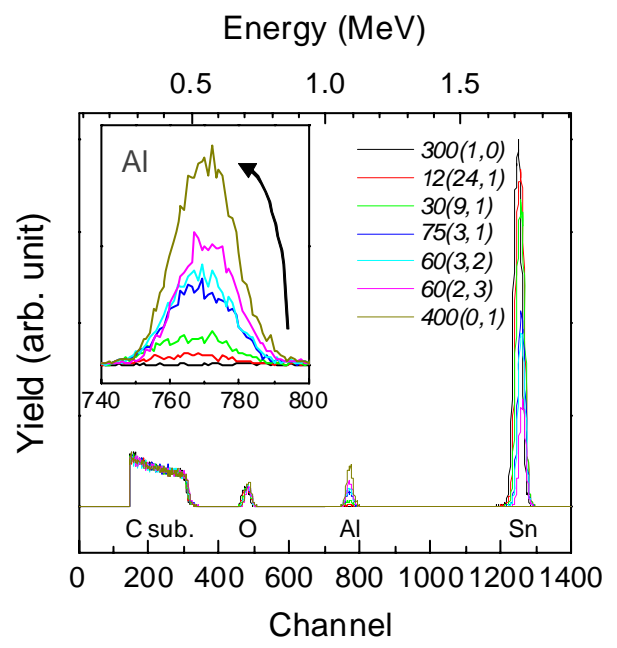

Figure 2. Rutherford backscattering spectra of $(\mathrm{Sn}, \mathrm{Al}) \mathrm{O}_{\mathrm{x}}$ composite films with various $\mathrm{Al}$ to $\mathrm{Sn}$ concentrations. The Al peaks are enlarged as an inset. The intensity of the Al peaks increase with increasing the percentage of $\mathrm{Al}_{2} \mathrm{O}_{3}$ subcycle. The notation $m(n, l)$ was used where $m, n$, and $l$ represent total repetitions, the number of $\mathrm{SnO}_{2}$ subcycle, and the number of $\mathrm{Al}_{2} \mathrm{O}_{3}$ subcycle, respectively. Total growth cycles were set to close to 300 cycles except 400 cycles for pure $\mathrm{Al}_{2} \mathrm{O}_{3}$ growth for comparison. 
Figure 3.

(a)

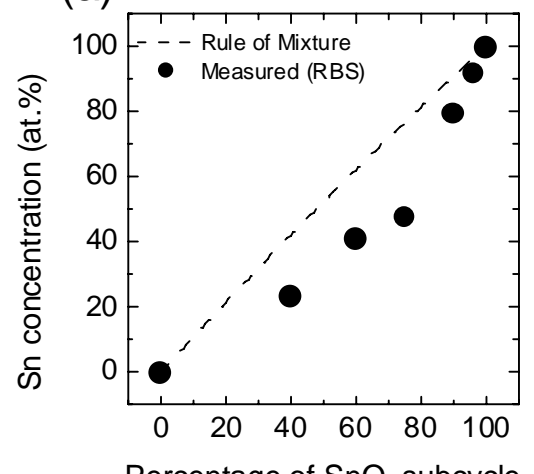

Percentage of $\mathrm{SnO}_{x}$ subcycle (b)

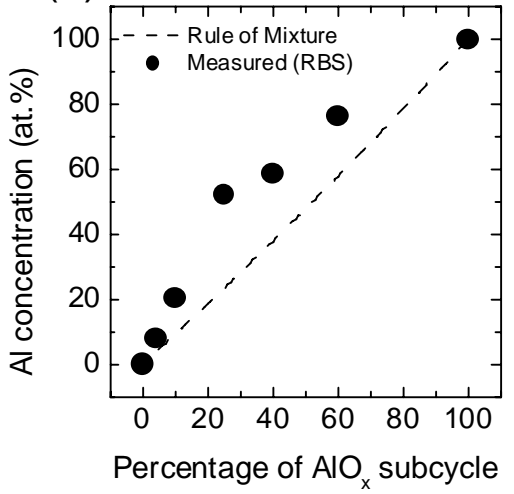

(c)

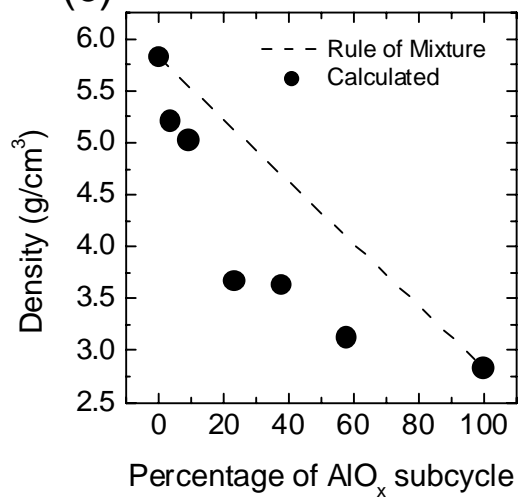

Figure 3. (a) Sn and (b) Al content ( \pm 1.5 at.\%) measured from RBS analyses as a function of the percentage of $\mathrm{SnO}_{2}$ and $\mathrm{Al}_{2} \mathrm{O}_{3}$ subcycle, respectively. Less $\mathrm{Sn}$ content was detected from RBS compared with the prediction from the rule of mixture (dotted lines) and vice versa for Al. (c) The film densities calculated using the concentrations of $\mathrm{Sn}, \mathrm{Al}$, and $\mathrm{O}$ atoms obtained from RBS analysis and the film thicknesses from XRR. 


\section{Figure 4.}

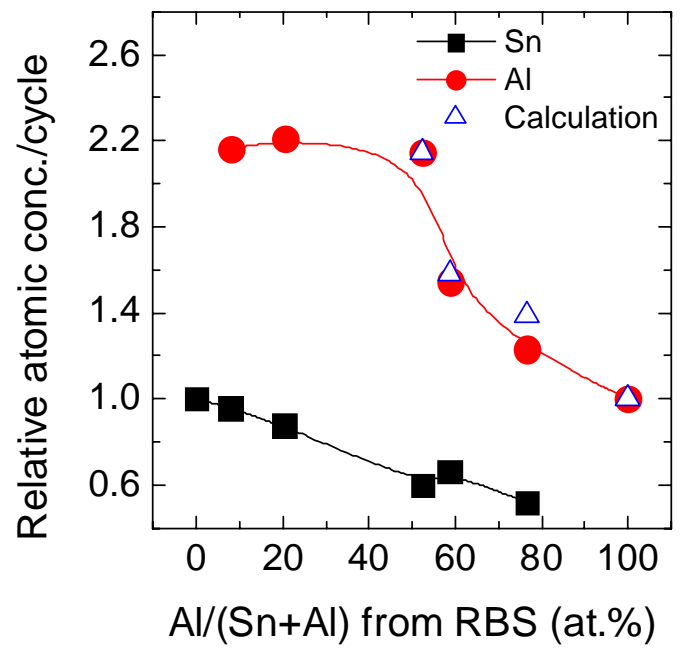

Figure 4. The relative cation concentration per unit area per cycle analyzed from RBS. The solid line is just for visual guidance. As the number of $\mathrm{Al}_{2} \mathrm{O}_{3}$ subcycles increase, the relative $\mathrm{Sn}$ concentration per cycle (closed squares, black color) gradually decreased. However, the relative Al concentration per cycle (closed circles, red color) stays at about 2.2 times higher than that of the undoped $\mathrm{Al}_{2} \mathrm{O}_{3}$ case (when the number of $\mathrm{Al}_{2} \mathrm{O}_{3}$ subcycles is one), then decreases when the $\mathrm{Al}$ concentration is higher than 50 at.\%, where the number of $\mathrm{Al}_{2} \mathrm{O}_{3}$ subcycle is 2 or more. Open triangles (blue color) represent the calculated average values of relative $\mathrm{Al}$ concentrations per cycle if first subcycle is $\sim 2.2$ times enhanced and the next subcycles are all the same thickness as on pure $\mathrm{Al}_{2} \mathrm{O}_{3}$. The simulated values well match with the measured values, suggesting that the chemisorption of TMA after one $\mathrm{Al}_{2} \mathrm{O}_{3}$ subcycle on $\mathrm{SnO}_{2}$ surface immediately recovers its own value for pure $\mathrm{Al}_{2} \mathrm{O}_{3}$. 


\section{Figure 5.}
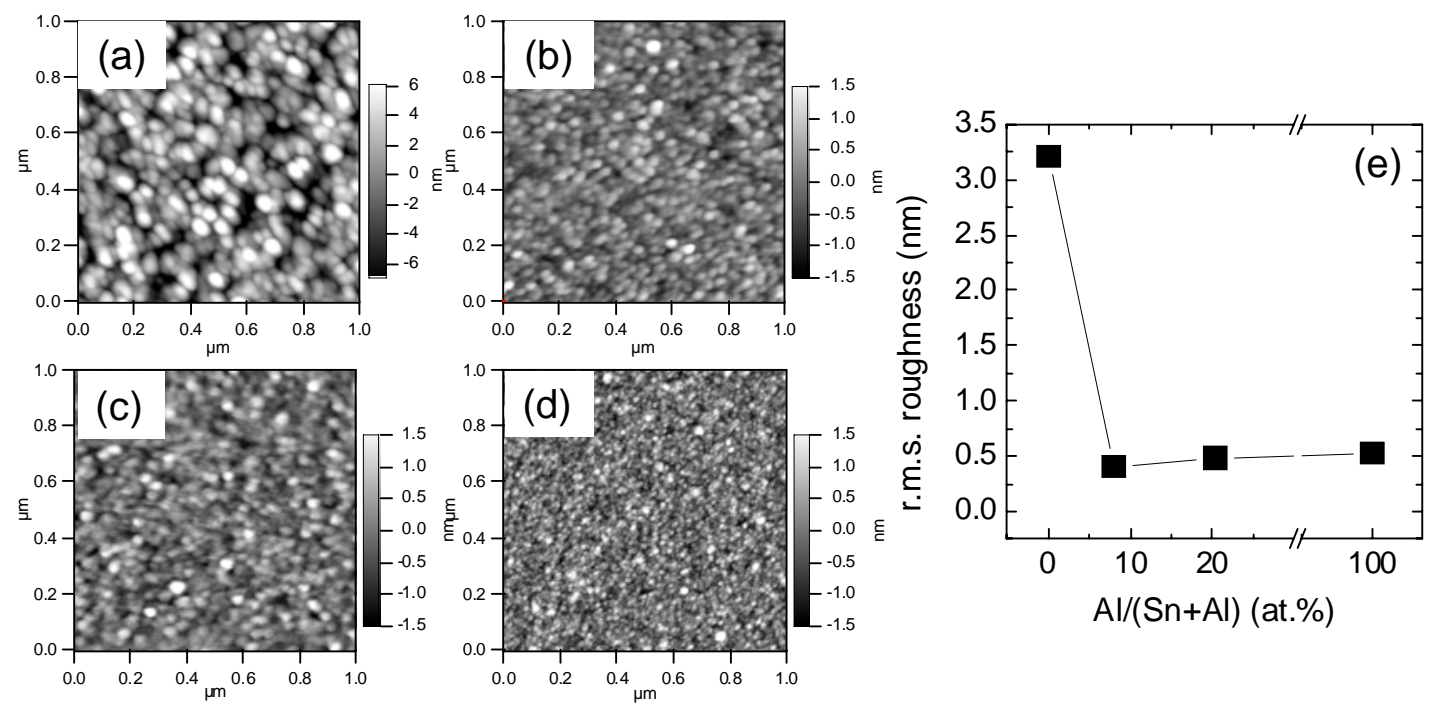

Figure 5. Surface morphologies of (a) $\mathrm{SnO}_{2}$ [556(1,0)], (b) 7.9 at.\% $\mathrm{Al}-\mathrm{SnO}_{\mathrm{x}}$ [30(24,1)], (c) 20.4 at.\% Al- $\mathrm{SnO}_{\mathrm{x}}[60(9,1)]$, and (d) $\mathrm{Al}_{2} \mathrm{O}_{3}[910(0,1)]$ observed by AFM. Total repetition $(m)$ of each sample was set to make the film thickness to $\sim 100 \mathrm{~nm}$. (e) The root-mean-square roughness $\left(\mathrm{R}_{\mathrm{s}}\right)$ as a function of $\mathrm{Al}$ concentration of the films. A drastic drop in $R_{\mathrm{s}}$ from 3.2 (a) to $0.41 \mathrm{~nm}$ (b) was observed when one subcycle of $\mathrm{Al}_{2} \mathrm{O}_{3}$ was inserted into $\mathrm{SnO}_{2}$. The $\mathrm{R}_{\mathrm{s}}$ values are very small (less than $0.5 \mathrm{~nm}$ ) for the $(\mathrm{Sn}, \mathrm{Al}) \mathrm{O}_{\mathrm{x}}$ composite films (b-c), as well as for $\mathrm{Al}_{2} \mathrm{O}_{3}$ (d). 


\section{Figure 6.}

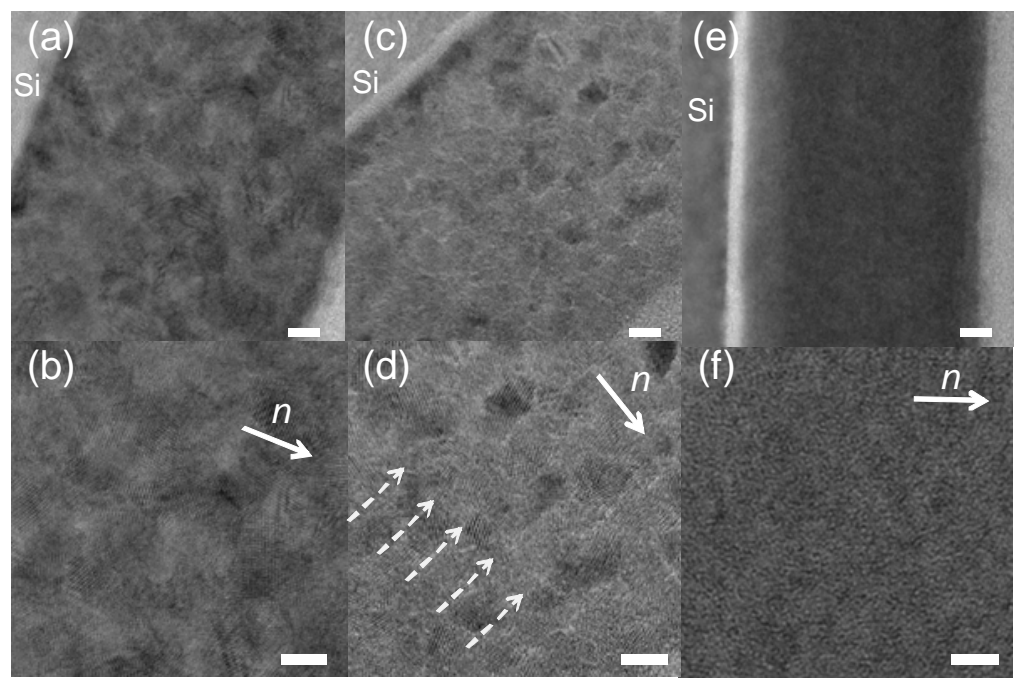

Figure 6. Cross-sectional TEM images of (a), (b) undoped $\mathrm{SnO}_{2}{ }^{36}$ (c), (d) 7.9 at.\% $\mathrm{Al}-\mathrm{SnO}_{\mathrm{x}}$, and (e), (f) 52.3 at.\% (Al,Sn) $\mathrm{O}_{\mathrm{x}}$ films. All scale bars represent $5 \mathrm{~nm}$. The direction normal to the Si substrate $(n)$ is noted with an arrow. Both undoped and 7.9 at. $\%$ Al- $\mathrm{SnO}_{\mathrm{x}}$ are polycrystalline. However, the nucleation of undoped $\mathrm{SnO}_{2}$ is random while the grains of 7.9 at.\% $\mathrm{Al}-\mathrm{SnO}_{\mathrm{x}}$ appear to align on one plane which is parallel to the substrate. It is seen from figure (c) that the number of the stacks of $\mathrm{SnO}_{2}$ grains is 12 , which is the repetition $(m)$ used in $12(24,1)$ sequence. Dotted arrows of figure (d) indicate the partially amorphous $\mathrm{Al}_{2} \mathrm{O}_{3}$ layers with brighter contrast than $\mathrm{SnO}_{2}$ grains. (e), (f) 52.3 at.\% ( $\left.\mathrm{Al}, \mathrm{Sn}\right) \mathrm{O}_{\mathrm{x}}$ film is amorphous. Somewhat thicker native $\mathrm{SiO}_{2}$ layer $(2-3 \mathrm{~nm})$ may be due to the beam damage during the sample preparation. 
Figure 7.

(a)

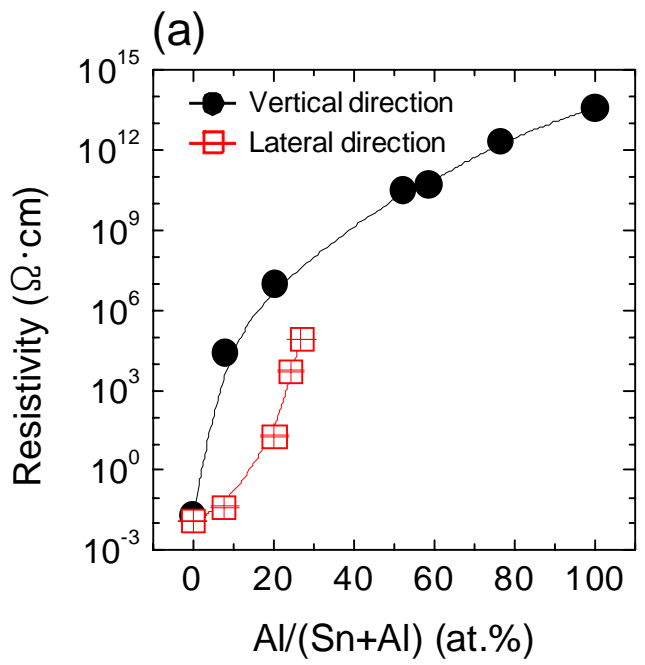

(b)

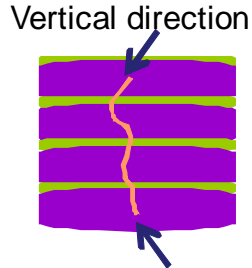

Lateral direction

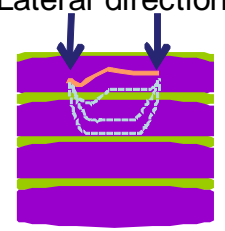

(c)

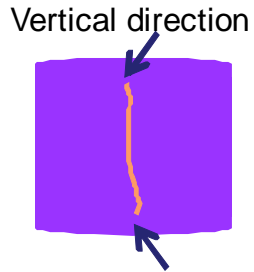

Lateral direction

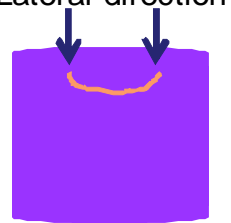

Figure 7. (a) The calculated resistivity as a function of atomic concentrations of Al for perpendicular current flow (closed circles) and lateral current flow (open squares). (b) Thin layers of green color represent $\mathrm{Al}_{2} \mathrm{O}_{3}$ (or Al-O-Sn) layers. Thick layers of violet color represent conducting $\mathrm{SnO}_{2}$ layers. The schematic explains why large anisotropy in resistivities happens at low concentrations of Al. (c) The schematic illustrates a homogeneous, amorphous mixture of $\mathrm{Al}_{2} \mathrm{O}_{3}$ and $\mathrm{SnO}_{2}$ that forms at higher $\mathrm{Al}$ concentrations, which explains the convergence of resistivity values for the two directions. 


\section{References}

(1) Hartnagel, H. L.; Dawar, A. L.; Jain, A. K.; Jagadish, C. Semiconducting Transparent Thin Films; IOP: Bristol, UK, 1995.

(2) Minami, T. Semicond. Sci. Technol. 2005, 20, S35-S44.

(3) Gordon, R. G. MRS Bull 2000, 25, 52-57.

(4) Gordon, R. G. US Patent 1981, 4,265,974.

(5) Proscia, J.; Gordon, R. G. Thin Solid Films 1992, 214, 175-187.

(6) Gordon, R. G. Mater. Res. Soc. Symp. Proc. 1996, 426, 419-429.

(7) Gordon, R. G.; Proscia, J.; Ellis, F. B.; Delahoy, A. E. Sol. Energy Mater. 1989, 18, 263-281.

(8) Gordon, R. G. J. Non-Cryst. Solids 1997, 218, 81-91.

(9) Chiang, H. Q.; Wager, J. F.; Hoffman, R. L.; Jeong, J.; Keszler, D. A. Appl. Phys. Lett. 2005, 86, 013503.

(10) Presley, R. E.; Munsee, C. L.; Park, C.-H.; Hong, D.; Wager, J. F.; Keszler, D. A. J. Phys. D: Appl. Phys. 2004, 37, 2810-2813.

(11) Huh, M. S.; Yang, B. S.; Oh, S.; Lee, J.; Yoon, K.; Jeong, J. K.; Hwang, C. S.; Kim, H. J. Electrochem. Solid-State Lett. 2009, 12, H385-H387.

(12) Govyadinov, A.; Emeliantchik, I.; Kurilin, A. Nucl. Instr. and Meth. Phys. Res. A 1998, 419, 667-675. 
(13) Beaulieu, D. R.; Gorelikov, D.; de Rouffignac, P.; Saadatmand, K.; Stenton, K.; Sullivan, N.; Tremsin, A. S. Nucl. Instr. and Meth. Phys. Res. A 2009, 607, 81-84.

(14) Drobychev, G.; Barysevich, A.; Delendik, K.; Nédélec, P.; Sillou, D.; Voitik, O. Nucl. Instr. and Meth. Phys. Res. A 2009, 610, 246-248.

(15) Kim, J. Y.; Lee, K.; Coates, N. E.; Moses, D.; Nguyen, T.-Q.; Dante, M.; Heeger, A. J. Science 2007, 317, 222-225.

(16) Suntola, T. Thin Solid Films 1992, 216, 84-89.

(17) Leskelä, M.; Ritala, M. Angew. Chem. Int. Ed. 2003, 42, 5548-5554.

(18) George, S. M. Chem. Rev. 2009, 110, 111-131.

(19) Leskelä, M.; Ritala, M. Thin Solid Films 2002, 409, 138-146.

(20) George, S. M.; Ott, A. W.; Klaus, J. W. J. Phys. Chem. 1996, 100, 13121-13131.

(21) Gordon, R. G.; Hausmann, D.; Kim, E.; Shepard, J. Chem. Vap. Deposition 2003, 9, 73-78.

(22) Puurunen, R. L. J. Appl. Phys. 2005, 97, 121301.

(23) Farmer, D. B.; Gordon, R. G. Nano Lett. 2006, 6, 699-703.

(24) Xuan, Y.; Wu, Y. Q.; Shen, T.; Qi, M.; Capano, M. A.; Cooper, J. A.; Ye, P. D. Appl. Phys. Lett. 2008, 92, 013101 .

(25) Choi, B. J.; Jeong, D. S.; Kim, S. K.; Rohde, C.; Choi, S.; Oh, J. H.; Kim, H. J.; Hwang, C. S.; Szot, K.; Waser, R.; Reichenberg, B.; Tiedke, S. J. Appl. Phys. 2005, 98, 033715. 
(26) Kim, J.-H.; Kim, J.-Y.; Kang, S.-W. J. Appl. Phys. 2005, 97, 093505.

(27) Hwang, G. W.; Lee, H. J.; Lee, K.; Hwang, C. S. J. Electrochem. Soc. 2007, 154, G69-G76.

(28) Lee, S. W.; Kwon, O. S.; Han, J. H.; Hwang, C. S. Appl. Phys. Lett. 2008, 92, 222903.

(29) Elam, J. W.; Routkevitch, D.; George, S. M. J. Electrochem. Soc. 2003, 150, G339-G347.

(30) Kim, S. K.; Choi, G. J.; Kim, J. H.; Hwang, C. S. Chem. Mater. 2008, 20, 3723-3727.

(31) Kim, S. K.; Choi, G.-J.; Lee, S. Y.; Seo, M.; Lee, S. W.; Han, J. H.; Ahn, H.-S.; Han, S.; Hwang, C. S. Adv. Mater. 2008, 20, 1429-1435.

(32) Elam, J. W.; George, S. M. Chem. Mater. 2003, 15, 1020-1028.

(33) Na, J.-S.; Peng, Q.; Scarel, G.; Parsons, G. N. Chem. Mater. 2009, 21 5585-5593.

(34) Yousfi, E. B.; Weinberger, B.; Donsanti, F.; Cowache, P.; Lincot, D. Thin Solid Films 2001, 387, 29-32.

(35) Elam, J. W.; Baker, D. A.; Hryn, A. J.; Martinson, A. B. F.; Pellin, M. J.; Hupp, J. T. J. Vac. Sci. Technol. A 2008, 26, 244-252.

(36) Heo, J.; Hock, A. S.; Gordon, R. G. Chem. Mater. 2010, 22, 4964-4973.

(37) Lee, D.-J.; Kim, H.-M.; Kwon, J.-Y.; Choi, H.; Kim, S.-H.; Kim, K.-B. Adv. Funct. Mater. 2011, $21,448-455$.

(38) Elam, J. W.; Groner, M. D.; George, S. M. Rev. Sci. Instrum. 2002, 73, 2981-2987. 
(39) Kumagai, H.; Matsumoto, M.; Kawamura, Y.; Toyoda, K.; Obara, M. Jpn. J. Appl. Phys. 1994, 33, 7086-7089.

(40) Hewett, C. A.; Taylor, M. J.; Zeidler, J. F.; Geis, M. W. J. Appl. Phys. 1995, 77, 755-760.

(41) Bierwagen, O.; White, M. E.; Tsai, M.-Y.; Nagata, T.; Speck, J. S. Appl. Phys. Express 2009, 2, 106502.

(42) Banerjee, A. N.; Maity, R.; Kundoo, S.; Chattopadhyay, K. K. Phys. Status Solidi A 2004, 201, 983-989.

(43) Du, X.; George, S. M. Sens. Actuators B 2008, 135, 152-160.

(44) Groner, M. D.; Fabreguette, F. H.; Elam, J. W.; George, S. M. Chem. Mater. 2004, 16, 639-645.

(45) Seki, K.; Tachiya, M. Journal of Physical Chemistry B 2004, 108, 4806-4810.

(46) Elam, J. W.; Sechrist, Z. A.; George, S. M. Thin Solid Films 2002, 414, 43-55. 